Aliran Eksistensialisme dalam Pandangan Filsafat Pendidikan Islam

Rabiatul Adawiah

Madrasah dan Transformasi Intelektual Muhdi

Kisah Keluarga Teladan dalam Al-Qur'an (Inspirasi Membangun Negara yang Thayyibah) Rahmat Sholihin

Tasawuf dalam Pandangan Nurcholish Madjid Ilham Masykuri Hamdie dalam Buku The Tao of Islam) Erni Susilawati

Islam, Keindonesiaan, dan Kemanusiaan

(Telaah Pemikiran Ahmad Syafii Maarif) Damanhuri

Pandangan Kritis Islam Liberal atas Isu-Isu Kontemporer Muhammad Taufik 


\section{AL - BANJARI \\ Jurnal Ilmiah Ilmu-Ilmu Keislaman}

Vol. 14, No. 1, Januari-Juni 2015

\section{DAFTAR ISI}

Aliran Eksistensialisme dalam Pandangan Filsafat Pendidikan Islam

Rabiatul Adawiah

Madrasah dan Transformasi Intelektual

Muhdi

Kisah Keluarga Teladan dalam Al-Qur'an (Inspirasi Membangun

Negara yang Thoyyibah)

Rahmat Sholihin

Tasawuf dalam Pandangan Nurcholish Madjid

Ilham Masykuri Hamdie

Psikologi Sufistik (Studi atas Pemikiran Sachiko Murata dalam Buku

The Tao of Islam)

60-75

Erni Susilawati

Islam, Keindonesiaan, dan Kemanusiaan (Telaah Pemikiran

Ahmad Syafii Maarif)

$76-84$

Damanhuri

Pandangan Kritis Islam Liberal atas Isu-Isu Kontemporer

85-105

Muhammad Taufik 


\title{
KISAH KELUARGA TELADAN DALAM AL QUR'AN (INSPIRASI MEMBANGUN NEGARA YANG THAYYIBAH)
}

\author{
Rahmat Sholihin \\ Dosen Fakultas Syariah dan Ekonomi Islam IAIN Antasari
}

\begin{abstract}
This article aims to discuss some exemplary family stories in the Koran that could be an inspiration to build a strong nation. This is because a great strong nation contains of individuals who grew up in families. Family, thus, became the first school (madrasah ula) for an individual. There are at least six families who become the focus of this paper; the family of Imran, Ibrahim as., Luqman, Ya'qub as, Daud as, and Syu'aib as. These Families can become inspirations in realizing the solid state and civil society.
\end{abstract}

Keywords: Exemplary Family, State and Civil Society.

\section{Pendahuluan}

Pepatah mengatakan: Hujan emas di negeri orang, masib lebih baik hujan batu di negeri sendiri. Tentulah pepatah ini tidak bermaksud untuk melecehkan negeri orang, tapi sekedar menunjukkan sifat seorang patriot yang harus bangga dengan bagaimanapun juga kondisi negerinya. Sifat patriotisme (semangat cinta tanah air) perlu ditumbuhsuburkan untuk membangun negeri sendiri menuju ke arah yang lebih baik lagi.

Membangun sebuah negeri yang baik (thayyibah) tidaklah semudah membalikkan kedua telapak tangan, perlu perjuangan, pengorbanan dan upaya yang terus-menerus dari generasi ke generasi. Perjalanan panjang dari keberhasilan sebuah negeri terbangun atas jerih payah generasi pendahulunya yang telah meletakkan dasar yang kokoh bagi generasi penerusnya.

Al-Quran telah menggambarkan Negeri Saba sebagai salah satu tanda kekuasaanNya sebagai sebuah negeri yang baik, dimana rezki dari Tuhan berlimpah dan dibarengi kesyukuran atas semua itu. Allah SW'T berfirman dalam Surah Saba ayat 15 sebagai berikut:

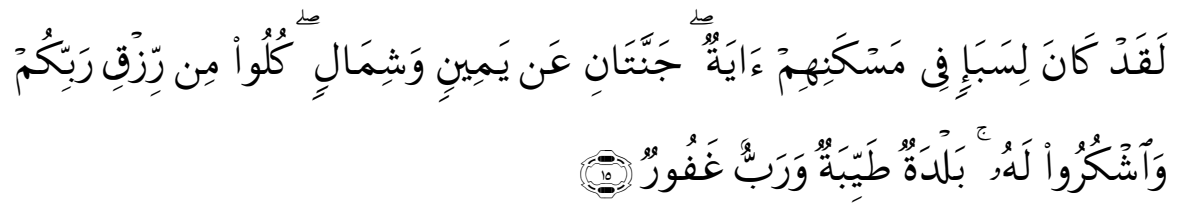


Sesunggubnya bagi kaum Saba' ada tanda (kekuasaan Tuhan) di tempat kediaman mereka Yaitu dua buah kebun di sebelab kanan dan di sebelah kiri. (kepada mereka dikatakan): "Makanlah olehmu dari rezki yang (dianugerabkan) Tubanmu dan bersyukurlab kamu kepada-Nya. (Negerimu) adalab negeri yang baik. dan (Tubanmu) adalab Tuban yang Maha Pengampun". (QS. Saba [34]: 15)

Dalam Tafsir Al-Mishbah, Quraish Shihab mengomentari kata thayyib (baik) dengan arti: sesuatu yang sesuai, baik dan menyenangkan. Negeri yang baik antara lain adalah negeri yang aman sentosa, melimpah rezekinya yang mudah didapatkan oleh penduduknya. Negeri yang penduduknya mempunyai pola hubungan harmonis sehingga kesatuan dan persatuan antar penduduk dapat terpelihara dengan baik. ${ }^{1}$

Menurut Al-Qurthubiy, adanya anak kalimat wa rabb ghafuur di belakang baldah thayyibah mengisyaratkan bahwa rezeki yang didapat adakalanya halal dan adakalanya haram. Aktivitas penduduknya juga tidak luput dari kemungkinan dosa dan kesalahan. Akan tetapi, wa rabb ghafuur agaknya menunjukkan bahwa penduduk Saba' relatif cepat menyadari kekeliruan dan kekhilafan untuk kemudian memohon ampun. Karena itu, ada penegasan bahwa Allah adalah Maha Pengampun. ${ }^{2}$

Negeri yang baik merupkan harapan semua orang. Rasulullah saw. pernah mengumpamakan masyarakat sebagai para penumpang kapal yang tengah mengarungi samudera. Hanya dengan kondisi kapal yang prima dan nakhoda yang baik lah perjalanan dapat dinikmati oleh semua penumpangnya. Demikian pula halnya dengan negara. Negara yang baik (baldah thayyibah) akan menjelma bila orang yang memimpin sekaligus sistem aturannya memungkinkan terwujudnya kebaikan tersebut. ${ }^{3}$

Setidaknya ada dua persyaratan penting yang harus terpenuhi demi terbangunnya sebuah negara yang sejahtera, kokoh, adil dan makmur, yaitu :

1. Pemimpin yang baik (uswah hasanah) sebagai inspirasi umat untuk mengikuti jejak langkahnya

2. Sistem yang baik. Sistem ini akan terbentuk dengan baik kalau didukung oleh seluruh lapisan masyarakat.

Keteladanan yang berawal dari lingkup terkecil (keluarga) dan pembiasaan (perilaku) yang baik sejak dini merupakan langkah yang efektif untuk membangun sebuah sistem sehingga akan terbentuk dengan baik.

Sejarah telah mengajarkan kepada kita, bahwa kemakmuran negeri Saba telah berubah menjadi malapetaka karena umatnya telah berpaling dan kafir terhadap ajaran agama. Sistem yang semula sudah tertata dengan baik menjadi hancur berantakan karena kekafiran dan keingkaran. ${ }^{4}$

Untuk menjaga keamanan dan kemakmuran suatu negeri, maka perlu diupayakan untuk melestarikan nilai-nilai agama di tiap generasi. Tradisi untuk taat beragama harus

${ }^{1}$ M. Quraish Shihab, Tafsir Al-Mishbah, Vol.11, (Jakarta: Lentera Hati, 2002), hlm. 363.

2 Al-Qurthubi, Al-Jami' Li Abkam al-Quran, Software Maktabah Syamilah.

${ }^{3}$ MR Kurnia, Menanti Negara Baldab Thayyibah, . Diakses tanggal 28 Januari 2012.

${ }^{4}$ Lihat QS. Saba [34]: 16-17. Wahbah Az-Zuhaili menafsirkan penyebab kehancuran negeri Saba adalah karena kekufuran, kesyirikan, mendustakan yang benar dan mengerjakan yang batil. Mereka telah kufur terhadap nikmat yang Allah berikan dan ingkar terhadap kerasulan. Lihat Wahbah Az-Zuhaili, At-Tafsir al-Munir fi al-Aqidah wa asy-Syariah wa al-Manhaj 
dimulai sejak dini dan dari lingkup terkecil dari sebuah masyarakat yaitu keluarga. Peran wanita sebagai ibu rumah tangga sangatlah penting dan menentukan bagi keharmonisan sebuah keluarga sebagai cikal bakal kokohnya sebuah negara.

\section{Peran Wanita Untuk Memperkokoh Negara}

Unit terkecil dari sebuah negara adalah keluarga. Dari lingkungan keluarga inilah nanti akan terbentuk sebuah negara. Kekokohan negara akan terbangun dengan baik jika tiap keluarga masing-masing memperhatikan perkembangan karekter anak-anak mereka sebagai generasi penerus bangsa.

Sebagai ibu, seorang istri adalah pendidik pertama dan utama bagi anak-anaknya, khususnya pada masa-masa balita. Memang, keibuan adalah rasa yang dimiliki oleh setiap wanita, karenanya wanita selalu mendambakan seorang anak untuk menyalurkan rasa keibuan tersebut. Mengabaikan potensi ini, berarti mengabaikan jati diri wanita. Pakar-pakar ilmu jiwa menekankan bahwa anak pada periode pertama kelahirannya sangat membutuhkan kehadiran ibu-bapaknya. Anak yang merasa kehilangan perhatian (misalnya dengan kelahiran adiknya) atau rnerasa diperlakukan tidak wajar, dengan dalih apa pun, dapat mengalami ketimpangan kepribadian.

Rasulullah Saw. pernah menegur seorang ibu yang merenggut anaknya secara kasar dari pangkuan Rasulullah, karena sang anak pipis, sehingga membasahi pakaian Rasul. Rasulullah SAW bersabda, "Jangan engkau menghentikan pipisnya. (Pakaian) ini dapat dibersibkan dengan air tetapi apakah yang dapat menghilangkan kekeruban dalam jiwa anak ini (akibat perlakuan kasar itu)?

Di sisi lain, Para ilmuwan juga berpendapat bahwa, sebagian besar kompleks kejiwaan yang dialami oleh orang dewasa adalah akibat dampak negatif dari perlakuan yang dialaminya waktu kecil. Oleh karena itu, dalam rumah tangga dibutuhkan seorang penanggung jawab utama terhadap perkembangan jiwa dan mental anak, khususnya saat usia dini (balita). Disini pula agama menoleh kepada ibu, yang memiliki keistimewaan yang tidak dimiliki sang ayah, bahkan tidak dimiliki oleh wanitawanita selain ibu kandung seorang anak.

Dalam literatur keagamaan dikenal istilah Wanita adalah tiang negara" Peristilahan "tiang" dianggap sebagai ilustrasi untuk menggambarkan betapa urgennya peran dan fungsi wanita. Kekuatan sebuah tiang dalam struktur bangunan akan sangat menentukan kokoh tidaknya bangunan itu. Dalam Islam, keshalihan seorang wanita tidak bisa dilepaskan dari ciri khasnya sebagai seorang muslimah.

Wanita shalihah akan mampu menjalankan perannya sebagai tiang negara, karena mereka telah berhasil menjalankan perannya sebagai pendidik utama dan pendamping hidup yang baik. Dari didikan wanita shalihah lah lahir para ilmuan yang beriman, pemimpin-pemimpin yang bertakwa, ekonom-ekonom yang jujur, pejabat-pejabat yang amanat dan seterusnya. ${ }^{7}$

\footnotetext{
${ }^{5}$ M. Quraish Shihab, Wawasan Al-Quran, (Yogyakarta: Mizan, 1996), hlm. 312.

${ }^{6}$ M. Fauzi Rahman, Haid Menghalangi Ibadab? No Way!, Ibadah-ibadah Utama bagi Perempuan Haid, (Bandung: PT. Mizan Pustaka, 2008), hlm 123.

7 M. Syafi'ie el-Bantanie, Bidadari Dunia, Potret Ideal Wanita Muslim, Jakarta: Quantum Media, 2006), hlm. 91.
} 
Penghargaan terhadap seorang wanita yang merangkap sebagai ibu sangatlah besar sekali. Kita sering menggunakan berbagai peristilahan yang merujuk kepada kata-kata "ibu", ada : ibu kota, ibu jari, ibu negara, ibu pertivi, bahasa ibu sampai kepada adanya peringatan hari ibu.

\section{Rumahku adalah Surgaku}

"Baity jannaty" adalah sebuah ungkapan yang biasa digunakan oleh umat Islam untuk menggambarkan betapa indahnya suasana suatu kediaman, tidak ada yang lebih indah dari surga, karena surga adalah puncak dari keindahan yang diciptakan oleh Yang Maha Indah.

Dalam beberapa literatur digambarkan bahwa kediaman sang Rasul pilihan ini sungguh sangat sederhana, bahkan jauh dari kesan sebagai kediaman seorang manusia pilihan. Hanya sepetak kamar, dengan beberapa peralatan rumah tangga dan sebuah tempat tidur didalamnya, yang kemudian tempat itu dijadikan juga sebagai pusaranya.

Dalam beberapa hadits dijelaskan bahwa seringkali Rasulullah SAW melakukan shalat sunnah di kediaman beliau, baru kemudian berangkat menuju masjid untuk menunaikan shalat wajib. Bahkan dalam suatu kesempatan Rasulullah SAW memerintahkan para shahabat agar melaksanakan sebagian ibadahnya dirumah masingmasing, agar rumahnya tidak menjadi seperti kuburan.

Rumah yang seperti kuburan sudah pasti tidak akan seperti surga, dan sudah bisa dipastikan juga akan membuat penghuninya tidak betah tinggal dirumah seperti itu. Maka memang sebaiknya rumah kediaman juga harus diprioritaskan untuk mendapatkan perlakuan istimewa, yaitu melaksanakan sebagian ibadah sunnah dirumah. Dari kegiatan ibadah itu tadi, rumah kediaman lambat laun akan menjadi surga dan kita betah tinggal didalamnya.

Eksistensi sebuah keluarga muslim akan terbina dengan baik dengan dukungan seluruh penghuni rumah. Kesadaran menjalankan perintah agama merupakan faktor utama kesuksesan sebuah rumah tangga untuk menjadikannya sebagai surga di dunia ini.

\section{Al-Quran Berkisah tentang Beberapa Keluarga Teladan}

Diantara metode Al-Quran memberikan petunjuk (Hudan) kepada umat manusia adalah dengan media kisah. Dengan media ini kaum yang beriman dan mau menggunakan nalarnya untuk memahaminya akan dapat memperoleh manfaat dalam menempuh kehidupan ini untuk sampai dengan selamat di akhirat kelak. Allah SWT berfirman dalam Surah Yusuf, ayat 111 sebagai berikut:

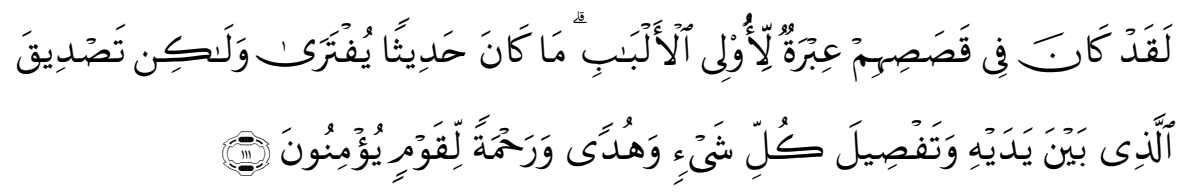

"Sesunggubnya pada kisah-kisah mereka itu terdapat pengajaran bagi orangorang yang mempunyai akal. Al Quran itu bukanlah cerita yang dibuat-buat, akan 
tetapi membenarkan (kitab-kitab) yang sebelumnya dan menjelaskan segala sesuatu, dan sebagai petunjuk dan rabmat bagi kaum yang beriman”. (QS. Yusuf [12]: 111)

Keluarga merupakan kelompok terkecil dalam sebuah masyarakat. maka baik buruknya sebuah masyarakat sangat bergantung kepada baik buruknya keluarga. Keluarga yang baik adalah awal dari masyarakat yang sejahtera. Sebaliknya, keluarga yang broken home adalah pertanda hancurnya sebuah masyarakat. Individu-individu yang baik akan membentuk keluarga yang harmonis. Keluarga-keluarga yang harmonis akan mewujudkan masyarakat yang aman dan damai. Selanjutnya masyarakat-masyarakat yang damai akan mengantarkan kepada negara yang kokoh dan sejahtera. Maka, jika ingin mewujudkan negara yang kokoh dan sejahtera bangunlah masyarakat yang damai. Dan jika ingin menciptakan masyarakat yang damai binalah keluarga-keluarga yang baik dan harmonis.

Dalam Al-Qur'an banyak terdapat potret keluarga sepanjang zaman. Ada potret keluarga saleh dan ada juga potret keluarga celaka. Potret-potret keluarga tersebut meskipun terjadi pada masa dan lingkungan yang berbeda dengan masa saat ini, akan tetapi ia tetap mengandung banyak hikmah dan pelajaran berharga yang senantiasa kekal sepanjang zaman. ${ }^{8}$

\section{Keluarga Imran}

Ada beberapa pelajaran berharga yang dapat dipetik dari potret keluarga Imran ini:

1. Apa yang menjadi keinginan besar dari istri Imran adalah bagaimana anaknya kelak menjadi abdi Allah seutuhnya. Bahkan, sebelum anaknya lahir ia telah bernazar bahwa anaknya akan diserahkan untuk menjadi pelayan di rumah Allah. Selayaknya, setiap orang tua muslim memiliki orientasi seperti halnya ibu Maryam ini. Ia tidak risau dengan nasib anaknya secara duniawi karena ia yakin bahwa setiap anak yang lahir sudah Allah jamin rezekinya. Apa yang menjadi buah pikirannya adalah bagaimana anaknya mendapatkan lingkungan yang baik untuk menjaga agama dan kehormatannya. Dengan orientasi seperti ini tidak mengherankan bila putrinya Maryam tumbuh menjadi seorang wanita yang paling suci di muka bumi. Lebih dari itu, ia dimuliakan oleh Allah dengan menjadi ibu dari seorang Nabi dan Rasul yang mulia; Isa bin Maryam melalui sebuah mukjizat yang luar biasa yaitu melahirkan anak tanpa seorang suami. Maka, orientasi orang tua tehadap anaknya adalah sesuatu yang sangat penting sebagaimana pentingnya membekali mereka dengan nilai-nilai keimanan sejak kecil.

2. Ketabahan dan kesabaran istri Imran dalam menerima takdir Allah swt. ketika anak yang dilahirkannya ternyata perempuan dan bukan laki-laki sebagaimana yang ia harapkan. Kesabaran dan sikap tawakal menerima keputusan Allah ini ternyata menyimpan rahasia yang agung bahwa kelak anak perempuan tersebut akan menjadi ibu seorang Nabi dan Rasul. Alangkah perlunya sikap ini diteladani oleh setiap keluarga muslim, terutama yang akan dikaruniai

\footnotetext{
${ }^{8}$ Kisah enam keluarga teladan ini disarikan dari tulisan Yendri Junaidi, Lc, Potret Keluarga Teladan Dalam Al-Quran, Al-Insan (Jurnal Kajian Islam), No.3, Vol.2, 2006, hlm 49 -53.
} 
seorang anak. Boleh jadi apa yang Allah takdirkan berbeda dengan apa yang diharapkan. Namun yang akan berlaku tetaplah takdir Allah, suka atau tidak suka. Maka, kewajiban seorang muslim saat itu adalah menerima segala takdir Allah itu dengan lapang dada dan suka cita, karena Allah tidak akan menakdirkan sesuatu kecuali itulah yang terbaik bagi hamba-Nya.

3. Maryam kecil akhirnya diasuh oleh Zakaria yang masih famili dekat dengan Imran. Tentu saja asuhan dan didikan Zakaria -yang juga seorang Nabi dan Rasul ini- sangat berdampak positif bagi pertumbuhan diri dan karakter Maryam, sehingga ia tumbuh menjadi seorang gadis yang suci dan terjaga harga dirinya. Dikisahkan bahwa ketika malaikat Jibril menemuinya dalam rupa seorang lelaki untuk memberi kabar gembira kepadanya tentang ia akan dikaruniai seorang putra, Maryam menjadi sangat takut melihat sosok lelaki asing yang tiba-tiba hadir di hadapannya. Hal itu tak lain karena ia memang tidak pernah bergaul dengan laki-laki manapun yang bukan mahramnya. Inilah sifat iffah (menjaga diri) yang didapat Maryam dari hasil didikan Zakaria. Untuk itu, setiap orang tua muslim selayaknya memilih lingkungan dan para pendidik yang baik bagi anak-anaknya, apalagi di usia-usia sekolah yang akan sangat menentukan pembentukan karakter dan pribadinya di masa-masa akan datang.

Seandainya orang tua keliru dalam memilih lingkungan dan sarana pendidikan bagi anak-anaknya, maka kelak akan timbul penyesalan ketika melihat anak-anaknya jauh dari tuntunan etika dan akhlak yang mulia.

\section{Keluarga Nabi Ibrahim as.}

Ada beberapa pelajaran yang ingin kita petik dari penggalan kisah keluarga Nabi Ibrahim as. ini:

1. Dialog yang baik dan harmonis antara seorang ayah dan anaknya. Meskipun Ibrahim meyakini bahwa perintah menyembelih anaknya itu mesti dilaksanakan, akan tetapi Ibrahim tetap melakukan dialog bersama putranya untuk meminta pendapatnya. Inilah barangkali yang mulai hilang dari keluarga muslim saat ini. Posisi anak dalam keluarga cenderung diabaikan dan dipandang sebelah mata. Anak seolah hanya berkewajiban untuk sekedar menuruti segala perintah orang tua tanpa memiliki hak bicara dan berpendapat sedikitpun. Akhirnya hubungan orang tua dengan anak ibarat hubungan atasan dengan bawahan. Hubungan seperti ini apabila dibiarkan terus berlanjut akan menghambat perkembangan karakter dan pribadi anak. Anak cenderung menjadi penakut dan tidak percaya diri. Atau kepatuhan yang ditampilkannya pada orang tua yang bersikap seperti ini hanyalah kepatuhan yang semu, sementara di dalam jiwanya ia menyimpan sikap penentangan dan pembangkangan yang luar biasa. Ia hanya mampu memendam sikap penentangan itu tanpa mampu melampiaskannya. Sikap penentangan ini akan menjadi bom waktu dalam jiwa anak yang suatu saat akan meledak jika situasi dan kondisinya mendukung.

2. Agar semua ini tidak terjadi, perlu dibangun komunikasi dan dialog yang 
harmonis antara orang tua dan anak. Kebiasaan orang tua yang selalu meminta pendapat anaknya -khususnya yang berhubungan langsung dengan dirinya- akan memberikan rasa percaya diri yang besar dalam jiwa anak. Ia akan merasa keberadaannya dalam keluarga dihargai dan diperhatikan. Selanjutnya, perasaan ini akan menumbuhkan sikap kreatif dan proaktif dalam jiwa anak di tengah-tengah masyarakat.

3. Kesabaran Ismail dalam menjalankan perintah Allah untuk menyembelih dirinya. Adalah sesuatu yang teramat berat untuk menjalankan perintah seperti ini, apalagi dari seorang anak yang masih sangat belia. Tentu saja ini adalah hasil dari sebuah didikan yang luar biasa. Pendidikan yang mampu menumbuhkan sikap tawakal yang luar biasa dalam jiwa anak. Pendidikan yang membuat anak bersedia menjalankan apapun perintah Allah, sekalipun akan mengorbankan nyawanya. Namun hal itu tidaklah mustahil, karena dalam rentang sejarah Islam juga banyak anak-anak yang sangat dewasa dalam menjalankan perintah Allah. Diriwayatkan bahwa anak-anak para salafusshaleh sering berpesan kepada ayahnya sebelum ayahnya pergi mencari nafkah: "Ayah, carilah rezeki yang halal, karena sesungguhnya kami mampu bersabar dalam kelaparan tapi kami tidak akan mampu bertahan dalam siksa neraka."[2] Tentunya sikap seperti ini hanya dapat dihasilkan melalui pendidikan yang serius sejak dini dengan menanamkan nilai-nilai keimanan dalam jiwa anak sedari kecil.

4. Kesabaran dan ketabahan dalam menjalankan perintah Allah akan selalu mendatangkan hasil terbaik. Ketika Ibrahim dan Ismail bersikap sabar dan tabah dalam menjalankan perintah Allah, meskipun itu sangat berat, Allah swt. menerima pengorbanan mereka dan menjadikan keluarga mereka sebagai keluarga pilihan di alam semesta. Mereka telah lulus menjalani sebuah ujian yang sangat berat. Kesabaran dan ketabahan dalam menjalankan perintah Allah itu hanya dapat diperoleh dengan keimanan yang kuat dan keyakinan yang kokoh bahwa kehendak Allah adalah yang terbaik meskipun bertentangan dengan hawa nafsu manusiawi.

5. Cinta pada anak adalah ujian. Oleh karena itu Allah swt. berfirman bahwa anak-anak dan istri bisa menjadi musuh bagi seseorang jika semua itu akan melalaikannya dari mengingat Allah swt. (at-Taghaabun: 14). Bagaimanapun cintanya orang tua kepada anaknya, hal itu tidak boleh menyamai apalagi melebihi cinta mereka kepada Allah. Ketika istri, anak-anak dan keluarga lebih dicintai daripada Allah, saat itulah mereka akan berubah menjadi musuh di akhirat kelak. Bahkan cinta kepada anak-anak tidak boleh melebihi cinta kepada Rasulullah saw. Dalam sebuah hadits, Rasulullah saw. bersabda: "Tidak sempurna iman seseorang diantara kamu sehingga aku lebih dicintainya dari anaknya, orang tuanya dan manusia seluruhnya."[3]

\section{Keluarga Luqman}

Ada beberapa nasehat yang diberikan Luqman kepada anaknya seperti yang tercantum dalam surat Luqman ayat 13 - 19: 
1. Jangan mempersekutukan Allah. Ini merupakan pelajaran aqidah yang paling mendasar yang mesti diberikan kepada anak sejak dini. Jika iman dan aqidah sudah tertanam dengan kuat dalam dirinya, niscaya ia akan tumbuh menjadi anak yang konsisten, penuh tanggung jawab dan tegar menghadapi segala cobaan hidup.

2. Berbakti pada kedua orang tua. Orang tua sebagai faktor lahirnya anak ke muka bumi adalah orang yang paling berhak untuk diberikan bakti oleh anak-anak. Begitu pentingnya berbakti kepada orang tua sampai-sampai dalam sebuah haditsnya Rasulullah saw. bersabda: "Keridhaan Allah terletak di atas keridhaan orang tua dan kemurkaan Allah terletak di atas kemurkaan orang tua."

3. Mendirikan shalat dan melaksanakan amar ma'ruf nahi mungkar. Pembiasaan ibadah kepada anak-anak sejak kecil sangat berguna untuk memberi kesadaran kepada mereka bahwa keberadaan mereka di dunia ini semata-mata hanyalah untuk mengabdi kepada Allah swt. Dengan demikian ia akan hidup dengan sebuah misi dan target yang jelas. Misinya adalah berubudiyah kepada Allah, sementara targetnya adalah mencapai ridha Allah.

4. Hal ini sekaligus juga akan menumbuhkan dalam diri anak keberanian memikul sebuah tugas dan tanggung jawab serta mampu bersikap disiplin. Sebab, semua jenis ibadah yang diajarkan oleh Islam mengajarkan kita untuk berani memikul amanah dan disiplin dalam menjalankannya. Di samping itu, yang dituntut dalam melaksanakan sebuah ibadah bukan sekedar lepas kewajiban, melainkan yang terpenting adalah pembentukan pribadi dan karakter yang baik yang tampak nyata dalam aktivitas sehari-hari sebagai buah yang positif dari rutinitas ibadah yang dikerjakan.

5. Jangan berlaku sombong. Nasehat ini sangat berharga bagi anak-anak sebagai bekal dalam pergaulan di tengah-tengah masyarakat. Jika ia ingin diterima oleh masyarakat, ia mesti menjauhi segala pantangan pergaulan dalam masyarakat. Karena, jika ia bersikap sombong maka secara tidak langsung sesungguhnya ia telah merendahkan orang lain. Dan siapapun orangnya sudah pasti memiliki harga diri dan tidak akan rela bila dipandang enteng dan diremehkan. Maka, modal utama pergaulan dalam masyarakat adalah sikap tawadhu' (rendah hati) dan tidak menganggap diri lebih dari orang lain.

\section{Keluarga Nabi Ya'qub as.}

Ada beberapa pelajaran yang ingin kita petik dari kisah keluarga Nabi Ya'qub ini:

1. Adalah sesuatu yang lumrah dan manusiawi bila hati seorang ayah atau ibu lebih condong kepada salah seorang anaknya dibanding yang lain. Rasa sayang yang lebih itu bisa jadi karena anak tersebut lebih patuh, lebih cerdas, lebih santun dan sebagainya. Hal itu tidak menjadi dosa bagi orang tua. Karena Al-Qur'an sendiri mengakui bahwa tidak seorangpun yang mampu berbuat adil secara sempurna (an-Nisa': 129). Yang dituntut oleh Islam dari orang tua adalah adil secara lahir. Artinya, meskipun secara batin dan di dalam hatinya ia lebih menyukai dan menyayangi salah seorang di antara anak-anaknya, 
akan tetapi dalam hal-hal yang tampak nyata ia wajib berlaku adil, seperti dalam mendidik, memberi nafkah, mencukupi segala kebutuhannya dan lain sebagainya. Orang tua akan berdosa seandainya rasa sayangnya yang berlebih pada beberapa orang anaknya membuatnya membeda-bedakan mereka dalam hak-hak secara lahir seperti pendidikan yang layak, uang belanja yang cukup, melengkapi kebutuhan sehati-hari dan sebagainya. Pada intinya, orang tua harus pandai dan bijak dalam membagi perhatiannya terhadap anak-anaknya sehingga tidak menimbulkan kecemburuan yang negatif dalam hati sebagian mereka.

2. Rasa cemburu yang berlebihan dan tak dapat dikendalikan bisa menjadi faktor yang sangat berbahaya dalam menghancurkan sebuah keluarga. Rasa cemburu ini dapat menghinggapi siapa saja. Suami cemburu pada istri atau sebaliknya, kakak cemburu pada adik atau sebaliknya dan seterusnya. Seorang yang merasa cemburu cenderung akan berusaha melampiaskan perasaannya dengan berbagai cara meskipun akan membahayakan jiwa saudaranya sendiri. Dalam kisah keluarga Nabi Ya'qub di atas, rasa cemburu telah menjerumuskan saudara-saudara Yusuf ke dalam lingkaran dosa yang panjang; mereka tega mencelakakan saudara sendiri, melanggar janji mereka semula untuk menjaga Nabi Yusuf, berbohong kepada ayah mereka dengan mengatakan bahwa Yusuf diterkam serigala dan seterusnya. Seorang ayah mesti menyikapi perasaan cemburu diantara anak-anaknya dengan baik dan penuh bijaksana. Sikap yang dipilih oleh Nabi Ya'qub menghadapi anakanaknya yang dihinggapi perasaan cemburu yang berlebihan itu adalah bersabar. Beliau hanya mengatakan: fashabrun jamiil (maka sabarlah yang lebih baik). Seandainya Nabi Ya'qub mengusir anak-anaknya yang telah menyia-nyiakan putra kesayangannya, tentu hal itu bukan sebuah solusi bijak dalam mendidik mereka, karena akhirnya mereka akan semakin lari atau bahkan membenci ayah mereka sendiri.

\section{Keluarga Nabi Daud as.}

1. Keluarga Nabi Daud adalah potret keluarga elit kekuasaan yang taat kepada Allah. Nabi Daud selalu menyuruh keluarganya untuk senantiasa mengerjakan shalat dan berzikir. Dikisahkan bahwa Nabi Daud memiliki waktu-waktu tertentu dimana ia bermunajat dan berzikir kepada Allah di mihrabnya. Di saat seperti itu, tak seorangpun yang boleh dan berani mengganggu beliau. Ternyata kekuasaan besar yang diberikan kepadanya sama sekali tidak menghalanginya untuk mengkhususkan sebagian waktunya tenggelam dalam lautan zikir kepada Allah.

2. Selain nuansa ibadah dan zikir, keluarga Nabi Daud juga kental dengan nuansa ilmu pengetahuan. Sudah jamak diketahui bahwa Nabi Daud adalah manusia pertama yang mampu mengolah besi dengan tangannya untuk berbagai keperluan terutama persenjataan perang. Di samping itu, Nabi Daud juga dikenal sebagai seorang raja yang adil dan bijaksana yang mampu memecahkan berbagai permasalahan yang paling rumit sekalipun dengan 
baik. Tentunya semua itu membutuhkan kecerdasan dan ilmu pengetahuan. Sifat ini kemudian diwarisi oleh putranya, yaitu Nabi Sulaiman. Bahkan dalam beberapa kasus, Allah swt. memberikan pemahaman yang lebih kepada Nabi Sulaiman, sehingga berkat ilmu dan kecerdasannya kasus-kasus tersebut dapat diselesaikan dengan penuh keadilan. Jadi, sebelum mereka berkuasa dengan kekuatan fisik dan senjata, mereka telah berkuasa lebih dahulu dengan kekuatan ilmu dan kecerdasan.

\section{Keluarga Nabi Syu'aib as. Bersama Kedua Puterinya}

Dari petikan kisah ini ada beberapa pelajaran berharga yang dapat kita ambil:

1. Nabi Syu'aib as. telah mengambil sebuah keputusan yang penuh bijaksana dan berani ketika ia ingin menikahkan salah seorang puterinya dengan seorang pemuda asing yang tidak memiliki apa-apa selain agama. Inilah faktor utama yang mendorong bagi Nabi Syu'aib untuk mengambil Nabi Musa sebagai menantu. Faktor ini pulalah yang seharusnya menjadi pertimbangan utama bagi setiap orang tua muslim dalam mencarikan jodoh untuk anaknya.

2. Bukanlah sebuah aib ketika orang tua menawarkan puterinya kepada seorang pemuda yang ia kagumi pribadi dan agamanya. Bahkan itu sudah menjadi hal yang lumrah di masa Rasulullah saw. dan salafusshaleh.

3. Didikan yang baik dari orang tua dapat menumbuhkan karakter yang baik dan kecerdasan pada diri anak. Hasil didikan Nabi Syu'aib terhadap puterinya tampak pada sifat malu dalam diri sang puteri saat ia disuruh ayahnya untuk mengundang Nabi Musa. Dalam sebagian riwayat disebutkan bahwa ketika pergi memanggil Nabi Musa ia mengenakan cadar untuk menutupi wajah dan menjaga 'iffahnya. Di samping pemalu, puteri Nabi Syu'aib juga seorang yang cerdas. Terbukti dari saran yang disampaikannya kepada ayahnya untuk mengupah Nabi Musa as. Ia berkata: "Sesungguhnya orang terbaik yang ayah upah adalah laki-laki yang kuat dan dapat dipercaya." Perkataan puteri Nabi Syu'aib ini mengajarkan kita bahwa kriteria utama yang mesti diperhatikan dalam memilih tenaga kerja dalam bidang apa saja adalah: al-qawiyy (punya kemampuan atau skill) dan al-amiin (dapat dipercaya).

\section{Eksistensi Keluarga dalam Pembangunan Bangsa}

Mengingat begitu pentingnya peranan keluarga dalam menciptakan masyarakat yang baik dan sejahtera, maka Islam memberikan perhatian yang sangat besar pada pembinaan keluarga. Seandainya instrumen terpenting dalam masyarakat ini tidak dibina dengan baik dan benar, adalah mustahil mengharapkan terwujudnya sebuah tatanan masyarakat idaman.

Eksistensi keluarga yang harmonis dan berkarakter adalah sebagai embrio terbentuknya sebuah negara yang besar, kokoh dan sejahtera. Harapan tertinggi dengan mencitakan sebuah negara yang besar haruslah dimulai dari sesuatu yang terkecil dengan mulai membangun sebuah keluarga yang ideal.

Menurut Nanang Qasim Yusuf bahwa derajat kepemimpinan manusia terdiri dari 6 macam, yaitu sebagai berikut: 
1. Memimpin (teladan) diri sendiri (mikrokosmos)

2. Memimpin (teladan) keluarga

3. Memimpin (teladan) masyarakat

4. Memimpin (teladan) negara

5. Memimpin (teladan) dunia

6. Memimpin (teladan) makrokosmos (alam semesta).

Dengan melihat pada macam tahapan pengembangan diri tersebut, maka sesuatu yang besar (makro) haruslah dimulai dari sesuatu yang kecil (mikro). Untuk bisa sukses memimpin sebuah negara, maka harus dimulai dari keberhasilan memimpin diri sendiri. Unit terkecil sebuah keluarga adalah merupakan miniatur sebuah negara dalam skala besar. Maka untuk membangun sebuah negara yang besar dan kokoh haruslah diawali dari kumpulan keluarga yang kokoh pula.

Keluarga adalah dasar landasan untuk mengajarkan dan menanamkan pada diri anggotanya rasa tanggung jawab, cinta kasih, kesabaran, toleransi, semangat berkorban, akal sehat, dan terbuka satu sama lain. Keadaan masyarakat yang stabil mengalir dari cara tiap-tiap keluarga menghayati hidup. ${ }^{10}$

Urgensi keluarga dalam mencetak pribadi-pribadi yang unggul dan berkarakter tidak disangsikan lagi. Berbagai perilaku yang baik diperoleh dari didikan di lingkungan keluarga, seperti: keadilan, kejujuran, kebaikan, keikhlasan, keyakinan, ukhuwah, pengorbanan, menghadapi kegagalan, kecerdasan sosial. ${ }^{11}$

\section{Simpulan}

Tokoh-tokoh besar lahir dari lingkungan keluarga kecil yang harmonis dan terdidik dengan baik. Kebesaran nama seorang tokoh harus dimaknai sebagai sebuah perjalanan panjang dari backgraound pendidikan awal di lingkungan keluarganya. Peran orang tua tidak bisa dianggap kecil. Dari didikan merekalah melahirkan pribadipribadi yang berkarakter.

Inspirasi beberapa keluarga teladan yang dikisahkan dalam Al-Quran banyak memberikan inspirasi untuk membangun sebuah masyarakat yang berperadaban, kokoh dan sejahtera. Wallahu' 'alam bi ash-shawab.

\section{Daftar Pustaka}

Abdul Azis Dahlan (et.al), Ensiklopedi Hukum Islam, Jakarta, PT. Intermasa, 2001.

Abdurrahman Ya'qub, Pesona Akblak Rasulullah saw, Mizania, 2002.

Bobby Herwibowo \& A. Hadi Yasin, The Power of Akhlak; Menjadi Kesayangan Allah, Jakarta, QultumMedia.

Ebta Setiawan, Kamus Besar Bahasa Indonesia offline, versi 1.1

\footnotetext{
${ }^{9}$ Nanang Qasim Yusuf, The Heart of 7 Awareness, (Jakarta: PT. Mizan Publika, 2008), hlm. 29.

${ }^{10}$ Niels Mulder, Southeast Asian Images: Toward Civil Sociaty?, Wacana Publik. Asia Tenggara; Menuju Masyarakat Madani, (Yogyakarta: Kanisius, 2005), hlm. 111.

${ }^{11}$ Lihat, Mulyanto, Kisah-kisah Teladan untuk. Keluarga; Pengasah Kecerdasan Spiritual, Jakarta: Gema Insani Press, 2004).
} 
Ibnu Jarir Ath-Thabari dalam kitab tafsirnya Jami' al-Bayan fi Ta'wil al-Quran, Software Maktabah Syamilah.

J. Kristiadi, Demokrasi dan Etika Bernegara, Yogyakarta, Kanisius, 2008.

Lihat, Mulyanto, Kisah-kisah Teladan untuk Keluarga; Pengasab Kecerdasan Spiritual, Jakarta, Gema Insani Press, 2004.

M. Fauzi Rahman, Haid Menghalangi Ibadah? No Way!, Ibadah-ibadab Utama bagi Perempuan Haid, Bandung, PT. Mizan Pustaka, 2008.

M. Quraish Shihab, Wawasan Al-Quran, Yogyakarta, Mizan, 1996.

M. Syafi'ie el-Bantanie, Bidadari Dunia, Potret Ideal Wanita Muslim, Jakarta, Quantum Media, 2006.

Nanang Qasim Yusuf, The Heart of 7 Awareness, Jakarta, PT. Mizan Publika, 2008.

Niels Mulder, Southeast Asian Images: Toward Civil Sociaty?, Wacana Publik Asia Tenggara; Menuju Masyarakat Madani, Yogyakarta, Kanisius, 2005.

Nourouzzaman Shiddiqi, Jeram-jeram Peradaban Muslim, Yogyakarta, Pustaka Pelajar, 1996.

Srijanti dkk, Etika Berwarga negara, Jakarta, Salemba Empat, 2008.

Taufiq Muhammad Asy-Syawi, Syura Bukan Demokrasi, Jakarta, Gema Insani Press, 1997.

Ali Margono, Etika dan Tata Susila Bernegara, , diakses tanggal 10 September 2011.

Anonim, Rasulullah SAW Pemimpin Sejati, , diakses tanggal 19 September 2011.

Budiyanto Eko Purnomo, Etika Bernegara dalam Perspektif Partai Keadilan Sejabtera, http://idb5.wikispaces.com/file/view/uf5008.pd, diakses tanggal 18 September 2011.

Komaruddin Hidayat, Etika Dalam Kitab Suci Dan Relevansiny a dalam Kebidupan Modern Studi Kasus di Turki, http://soni69.tripod.com/artikel/ Kasus_Turki.htm diakses tanggal 17 September 2011.

MR Kurnia, Menanti Negara Baldab Thayyibah,

Syaiful Alamsyah, Zalim, http://www.scalamedia.net/artikel/obrolan-siang/385zalim.html, diakses tanggal 18 September 2011.

Yendri Junaidi, Potret Keluarga Teladan Dalam Al-Quran, Al-Insan (Jurnal Kajian Islam), No.3, Vol.2, 2006, diakses tanggal 10 September 2011. 